\title{
Factors That Influence the Tax Compliance: An Empirical Study Among Individual Taxpayers as Business Owners in West Jakarta
}

\author{
Andreas Bambang Daryatno ${ }^{1}$, Linda Santioso ${ }^{1 *}$ \\ ${ }^{1}$ Faculty of Economics and Business, Universitas Tarumanagara, Jakarta, Indonesia \\ *Corresponding author. Email: lindas@fe.untar.ac.id
}

\begin{abstract}
This study aimed to obtain empirical evidence regarding the effect of self assessment, tax knowledge, moral responsibility, tax sanctions, and service quality on tax compliance in fulfilling the tax obligations. The data in this study was primary data obtained from the respondents' answers through research questionnaire. The respondents in this study were individuals who are business owners in West Jakarta. Samples were taken by using simple random-sampling technique. The data analysis tool was the Structural Equation Model (SEM) using Lisrel 8.8 software. The results of data analysis prove that tax knowledge, moral responsibility, and service quality have positive influences, while the self-assessment system and tax sanctions do not have influences on tax compliance.

Keywords: Self assessment, Tax knowledge, Moral responsibility, Tax sanctions, Service quality, Tax compliance
\end{abstract}

\section{INTRODUCTION}

Based on data from the Indonesia Ministry of Finance [25][26], tax revenues reached $\mathrm{Rp} 1,786.4 \mathrm{~T}$ consisting of Rp 655.4 T from VAT receipts, Rp 894.4 T from IncomeTax receipts and $\mathrm{Rp} 236.6 \mathrm{~T}$ from export duties, import duties, and other paid taxes. The dominance of Tax Revenues reached $82.5 \%$ in the 2019 State Budget, while the Non-Tax State Revenues contributed as much as $17.5 \%$, and still has the potential to be increased. Every year, the government always experiences a deficit, and one of the government's efforts to cover the deficit is through the debt financing. Government's debt reached IDR 4,814.31 as of November 2019 [25]. This government's debt reached $30.03 \%$ whereas the limit set by law is maximum $60 \%$ of Gross Domestic Product (Article 12 Paragraph 3 of the State Finance Law). Why did the Indonesian government go into debt? This happens because the government's revenue from the tax-sector cannot cover the financing needs based on the State Budget.

The General Directorate of Tax (GDT) continues to reform itself and strive for the majority of revenue to be increased. Reformations are done in form of changes to regulations or laws that are continued to be carried out gradually by the government so that the State Revenue can be increased from policies, counseling, tax sanctions, to law enforcement. The self assessment and withholding system adopted and implemented in Indonesia still opens the opportunities for individual and corporate taxpayers to pay their taxes that are not in accordance with the applicable laws and regulations.

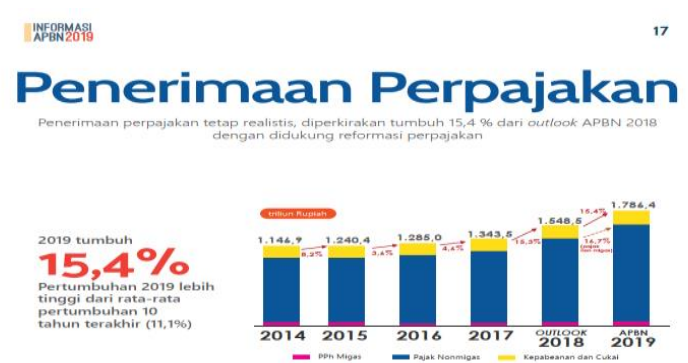

Figure 1 State-Revenue Rate Source: Ministry of Finance, Republic of Indonesia

This is evidenced by the slowing pace of state revenues in 2014-2019 (Figure 1) and the tax-ratio of tax revenue is weakening (Figure 2).

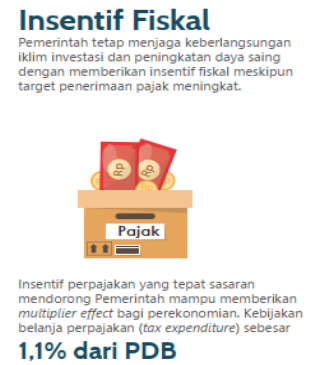

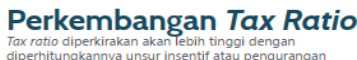

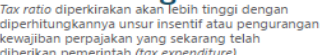

Figure 2 Tax-Ratio of Tax Receipts

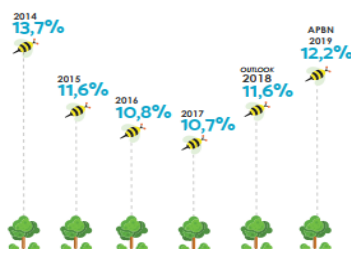

Source: Ministry of Finance, Republic of Indonesia

Based on previous research, the trust given by the government to taxpayers to calculate, deposit, and report 
their tax obligations, should be utilized by taxpayers to fulfill their obligations. This is proven by the research that produces a self-assessment system that is in quite good category [13]. However, the state's revenue from the tax sector has never reached the government's target that has been set every year. The tax ratio only reached $12.2 \%$ in 2019 , and when being compared to other countries, it is very low. Actually, many problems are experienced by the Indonesian nation, with all the efforts, reformations, and facilities provided by the government through the General Directorate of Taxes. The fact is that the taxpayers are not considered to be maximum in paying their taxes

Even though it is viewed from previous research, taxpayers with high knowledge should have a high influence on the implementation of fulfilling their tax obligations. The more knowledge understanding they have, the better the taxpayers will carry out their tax obligations [4]. Besides, taxpayers' compliance can also be influenced by moral responsibility. Moral responsibility has a positive effect on taxpayers' compliance. If the taxpayers' moral responsibilities increases, their compliance will also increase [10].

Tax sanctions are also one of the factors affecting the level of tax compliance. Tax regulations and laws that have been established by the government must be obeyed by taxpayers. Tax penalties are proven to have a positive effect on taxpayer compliance [10]. The quality of service of tax officers is also very influential on taxpayers' compliance in paying and reporting their taxes. Quality of service has a positive influence on taxpayers' compliance. Tax officials must provide good service for taxpayers to improve the taxpayers' compliance, such as officers who are polite in serving taxpayers and are responsive in solving the problems faced by taxpayers [10].

Based on the explanation above, the problem formulations can be developed as follows:

1. Does the Self Assessment System have a positive influence on Taxpayers' Compliance?

2. Does Taxation Knowledge have a positive influence on Taxpayers' Compliance?

3. Does Moral Responsibility have a positive influence on Taxpayers' Compliance?

4. Does the Tax Sanction have a positive influence on Taxpayers' Compliance?

5. Does Service Quality have a positive influence on Taxpayers' Compliance?

The research objective is to prove empirically the effects of self assessment system, tax knowledge, moral responsibility, tax sanctions, and service quality on taxpayers' compliance.

The benefit of this research is that the results are expected to provide an input, consideration, and evaluation by tax regulators. This study pays more attention to what factors that are related to tax compliance in making tax rules or regulations so that the tax revenue target can be met.

\section{LITERATURE REVIEW}

\subsection{Taxpayers' Compliance}

It is an obligation for citizens to obey / comply with the policies or regulations made by the government. When the government makes taxation laws, all citizens who are taxpayers can exercise all their tax rights and responsibilities. Taxes paid by the taxpayers to the state treasury based on the law are used to finance the state expenditures [24]. Santoso (2008) in [3] stated that taxpayers' compliance occurs when they carry out all rights and tax obligations in accordance with the applicable law. According to Simon James et al. (2003) in [3], taxpayers comply in a situation whereas they have awareness in fulfilling their tax obligations under applicable laws without the threat of inspection, fine sanctions, administrative sanctions, and even criminal sanctions.

Meanwhile, according to [1], the compliance of taxpayers is influenced by several factors, namely the level of tax rates, service tax officers on taxpayers, law enforcement, and tax audits.

\subsection{Self-Assessment System}

Self-assessment system is a tax collection system that gives taxpayers the authority to determine their own tax amount owed each year in accordance with applicable tax laws and regulations [20].

According to [3], the self-assessment system has a pretty good influence on taxpayers' compliance in fulfilling their obligations. The influence of taxpayers reaches $46.0 \%$ while the rest is influenced by factors outside the study such as the administration system, services, law enforcement, and tax rates.

\subsection{Tax Knowledge}

It was revealed that; tax knowledge has no impact on tax compliance. It is, therefore, recommended that the efforts can be made to improve the taxpayers' knowledge so as to improve their tax compliance and consequently improve the government's revenue generation [6].

According to [22], tax knowledge depends on the general provisions, types of taxes, tax subjects and objects, tax rates, the calculation of tax payable, and tax reporting.

\subsection{Moral Responsibility}

[14] mentioned that the public does not want to pay taxes (passive), due to the intellectual and moral development of the community, the taxation system is difficult, and the level of control is difficult to do.

The results of data analysis according to [19] show that moral responsibility has a positive and significant effect on reporting compliance among individual taxpayers. However, taxpayer awareness, tax sanctions, and service 
quality have no effect on individual taxpayer reporting compliance.

\subsection{Tax Sanctions}

Tax sanctions are tools to prevent taxpayers from violating the tax laws [14]. Taxpayers will carry out their obligations properly and will avoid tax penalties, because making tax payments will be greater and detrimental. According to [14], there are 3 types of administrative sanctions, namely in form of fines, interests, and tax increases; whereas criminal sanctions are a bastion of law used by the tax authorities so that tax norms are obeyed. There are 3 types of criminal sanctions, namely: criminal fines, confinement, and imprisonment. Everything has been regulated by the law, so anyone who violates it will be a subject to sanctions in accordance with the applicable regulations. With a selfassessment system, taxpayers become aware of every law and regulation issued by the government. Taxpayers understand the rights and obligations of taxation by force and taxpayers also understand the risks that will occur if they violate. Preparation and outreach to the public is very necessary to improve tax knowledge and understanding so that the public can be orderly, obedient to the tax regulations, and the target of state revenue from the taxsector can be achieved properly. By this way, the government can be independent in financing all expenses specified in the State Budget.

\subsection{Quality of Service}

The result of previous study shows that service quality affects service satisfaction, and it implies compliance with the personal-vehicle tax-payable compliance. Besides, the tax sanctions affect service satisfaction, and it implies the compliance in paying personal vehicle-tax. Tax sanctions are a prevention tool for violations committed by taxpayers. If service satisfaction fails to meet expectations, the taxpayers will feel dissatisfied. If service satisfaction is in line with expectations, the taxpayers will feel satisfied. And if service satisfaction exceeds expectations, then the taxpayers will be very satisfied [9].

\subsection{Hypothesis Development}

\subsubsection{The Effect of Self-Assessment System on Personal Taxpayers' Compliance}

Self-assessment system can work well if the taxpayers have high knowledge, moral responsibility, and tax discipline, which includes the taxpayers' trust in the country. The selfassessment system provides an opportunity for taxpayers to calculate, deposit, and report their taxes and even the manipulation of the calculation of tax payable as well as other acts of fraud. According to [13], the self-assessment system has a pretty good influence on taxpayers' compliance in fulfilling their obligations. The influence of taxpayers reaches $46.0 \%$ while the rest is influenced by factors outside the study such as the administration system, services, law enforcement, and tax rates.

$\mathrm{H}_{1}$ : Self-assesment system has a positive influence on personal taxpayers' compliance.

\subsubsection{The Effects of Tax Knowledge on Personal Taxpayers' Compliance}

The level of knowledge and understanding of taxpayers towards the taxation has a role in determining the compliance of taxpayers in carrying out their taxation rights and obligations. The taxpayers' understanding about the procedures for calculating, depositing, and reporting based on the applicable laws and regulations, will increase their compliance. Based on the research that has been conducted, especially the empirical research by [4] and [21], tax knowledge has an influence on taxpayers' compliance while an empirical research conducted by [6] shows that tax knowledge has no effect on taxpayers' compliance.

$\mathrm{H}_{2}$ : Tax knowledge has a positive influence on personal taxpayers' compliance.

\subsubsection{The Effect of Moral Responsibility on Personal Taxpayers' Compliance}

The results of the study conducted by [12] show that the higher moral of tax ethics that the taxpayers have, the lower the taxpayers' intention to avoid the tax. [10] mentioned that moral responsibility has a positive and significant effect on taxpayers' compliance. High moral responsibility will increase the taxpayers' reporting compliance.

$\mathrm{H}_{3}$ : Moral responsibility has a positive influence on personal taxpayers' compliance.

\subsubsection{The Effect of Tax Sanctions on Personal Taxpayers' Compliance}

High and low taxpayers' compliance can be influenced by the tax sanctions. Basically, tax sanctions are imposed to punish and make taxpayers not violate the applicable regulations. Taxpayers understand the risks of breaking the law and what they will receive if they do not comply. [10] stated that tax sanctions affect taxpayers' compliance while the research conducted by [16] and [21] shows that tax sanctions do not affect the taxpayers' compliance.

$\mathrm{H}_{4}$ : Tax sanctions have a positive influence on personal taxpayers' compliance.

\subsubsection{The Effect of Service Quality on Personal Taxpayers' Compliance}

[10] concluded that the quality of service by tax officers has a positive and significant effect on taxpayers' compliance, but another research conducted by [16] shows that the quality of service by tax officers does not have any effect on taxpayer's compliance.

$\mathrm{H}_{5}$ : Service quality has a positive influence on personal taxpayers' compliance. 
Based on the hypothesis development above, the research model can be described as follow:

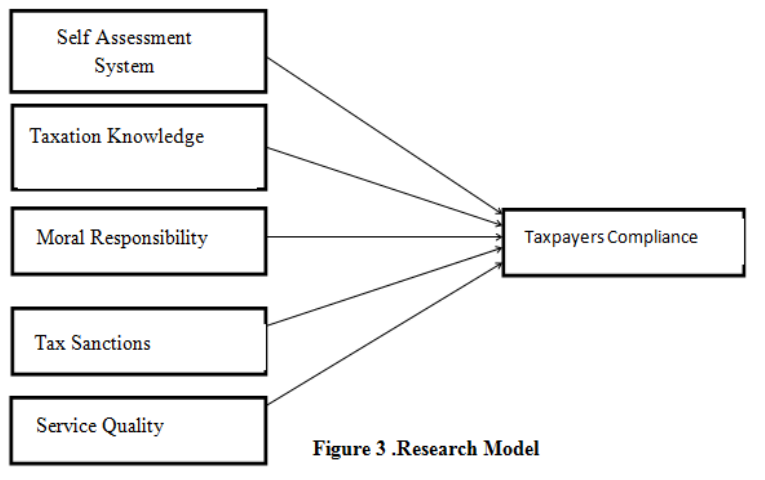

\section{RESEARCH METHODS}

\subsection{Population and Samples}

This study used primary data, and the data was obtained from the questionnaires distributed to respondents. The population used is the individual taxpayers. The sample used is individual taxpayers who have independent business living in West Jakarta. The sampling method used is Simple Random Sampling which means that each member in the population can be sampled on the same occasion. The respondent's criterion is an individual taxpayer who has his or her own business.

\subsection{Operationalization of Variables}

The variables used in this study are Self-Assessment System, Tax Knowledge, Moral Responsibility, Tax Sanctions, and Service Quality as independent variables (Exogenous Variables) and Taxpayers' Compliance as a dependent variable (Endogenous Variable).

The indicators of the self-assessment system variable are knowing the regulations and understanding the taxes; calculating, depositing, and reporting the taxes; following the changes in tax regulations; tax rates; knowing and implementing the self-assessment system. The indicators of the tax-knowledge variable are understanding tax regulations and changes; regulations make it easier to calculate, deposit, due, and report the taxes; know the functions, sanctions, taxed and non-taxed income, rights and obligations. The indicators of the moral Rresponsibility variable are shared-responsibility tax; the anxious and guilty of tax evasion; calculating, depositing, reporting correctly and voluntarily. The indicators of the tax-sanction variable are administrative sanctions, heavy sanctions, and even criminal sanctions for the violators of tax regulations. The indicators of the service quality variable are the officers providing services, information; assisting and solving the taxpayers' problems; the neatness, comfort and friendliness of officers; knowledge and communication of officers. The indicators of the taxpayers' compliance variable are understanding the regulations; filling in such as, calculating and depositing on time, tax documents, allocating funds, and voluntary obligations.

\subsection{Descriptive Statistics}

From the results of descriptive statistics, Variable $\mathrm{X}_{1}$ ranges between 18,000 and 35,000; Variable $\mathrm{X}_{2}$ ranges between 23,000 and 44,000; Variable $\mathrm{X}_{3}$ ranges between 12,000 and 20,000; Variable $\mathrm{X}_{4}$ ranges between 9,000 and 20,000; Variable $\mathrm{X}_{5}$ ranges between 15,000 and 36,000.

\subsection{Data Normality}

Data normality was tested using skewness and kurtosis, whereas the $\mathrm{p}$-value obtained for $\mathrm{X}_{1}=0.344$, for $\mathrm{X}_{2}=0.084$, for $X_{3}=0.192$, for $X_{4}=0.145$, and for $X_{5}=0.000$.

\section{ANALYSIS AND DISCUSSION}

The questionnaire was distributed to 120 respondents, of which 5 questionnaires were not returned and 3 questionnaires were incomplete so that the number of questionnaires that could be processed was 112 . Respondents are the individual taxpayers who domiciled in West Jakarta.

In the Structural Equation Model (SEM), a study does not only depend on one index or several fit-indexes, but must also consider all fit-indexes. Therefore, the indicators of goodness-of-fit in examining the fit of a result model from Lisrel 8.8 output are as follows:

Table 1 Goodness-of-Fit Statistics

Goodness of Fit Statistics
Degrees of Freedom $=8$
Minimum Fit Function Chi-Square $=32.34(\mathrm{P}=0.00)$
Normal Theory Weighted Least Squares Chi-Square $=$
$29.83(\mathrm{P}=0.00023)$
Satorra-Bentler Scaled Chi-Square $=30.30 \quad(\mathrm{P}=$
$0.00019)$
Chi-Square Corrected for Non-Normality $=33.63(\mathrm{P}=$
$0.00)$
Estimated Non-centrality Parameter $(\mathrm{NCP})=22.30$
90 Percent Confidence Interval for NCP $=(9.06 ; 43.10)$
Minimum Fit Function Value $=0.29$
Population Discrepancy Function Value $(\mathrm{F} 0)=0.20$
90 Percent Confidence Interval for F0 $=(0.082 ; 0.39)$
Root Mean Square Error of Approximation $(\mathrm{RMSEA})=$
0.16
90 Percent Confidence Interval for RMSEA $=(0.10 ;$
$0.22)$
P-Value for Test of Close Fit $(\mathrm{RMSEA}<0.05)=0.0020$
Expected Cross-Validation Index $(\mathrm{ECVI})=0.51$
90 Percent Confidence Interval for ECVI $=(0.39 ; 0.69)$
ECVI for Saturated Model $=0.38$
ECVI for Independence Model $=1.07$
Chi-Square for Independence Model with 15 Degrees of
Freedom = 106.49
Independence AIC $=118.49$




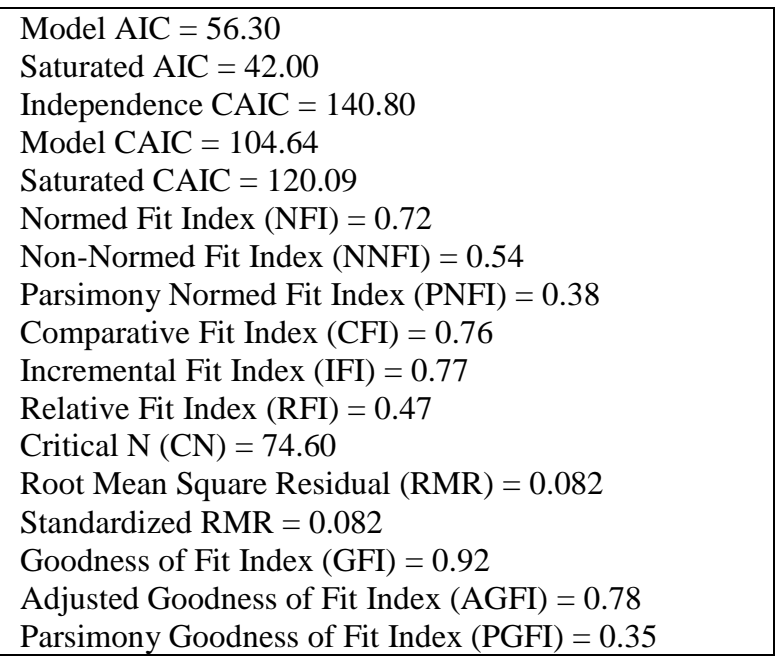

Source: Processed Primary Data

\subsection{Model Compatibility Test}

Based on the results of the Goodness-of-Fit Statistics, a fit test (Testing Fit) is conducted [7], of which the results are as follows:

\section{Table 2 Testing Fit}

\section{Goodness of Fit Statistics}

Degrees of Freedom $=0$

Minimum Fit Function Chi-Square $=0.0(\mathrm{P}=1.000)$

Normal Theory Weighted Least Squares Chi-Square $=$ $0.00(\mathrm{P}=1.000)$

The Model is Saturated, the Fit is Perfect!

Source: Processed Primary Data

\subsection{Evaluation of Measurement Model}

The evaluation of measurement model is focused on the relationships between latent variables and indicators (variable manifests). The purpose of evaluating the measurement model is to determine the validity and reliability of indicators of a construct. The validity test aims to determine the ability of an indicator in measuring latent variables, while the reliability test aims to determine the consistency of the measurement of indicators of a latent variable. The output of the Lisrel 8.8 Program produces PHI-X and PSI Y as follows:

Table 3 PHI-X and PSI-Y

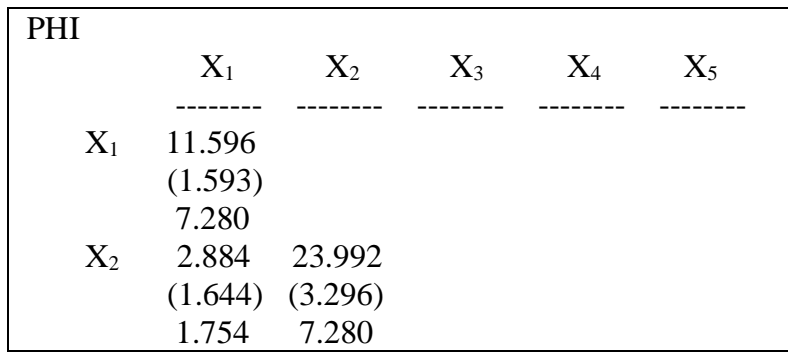

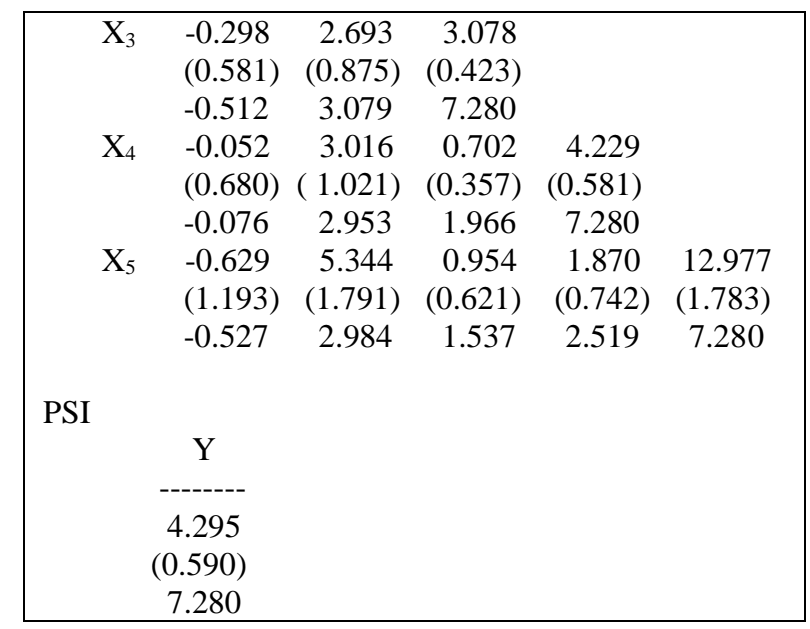

Source: Processed Primary Data

PHI-X is a matrix that connects the exogenous or independent latent variables with its indicators (variable manifest / variable observed). With the t-Table of $\alpha=5 \%$ $( \pm 1.96)$, the results of all the above indicators are as follows:

a. $\mathrm{X}_{1}$ (Self-Assessment System) has a covariance level of 11,596, standard error of $(1,593)$ and t-value of 7.280 (> 1.96), which means that the indicators of $X_{1}$ are significant at $\alpha=5 \%$.

b. $\mathrm{X}_{2}$ (Tax Knowledge) has a covariance level of 23.992, standard error of (3.296) and t-value of 7.280 (> 1.96), which means that the indicators of $\mathrm{X}_{2}$ are significant at $\alpha=5 \%$.

c. $\mathrm{X}_{3}$ (Moral Responsibility) has a covariance level of 3.078, standard error of (0.423) and t-value of 7.280 (> 1.96), which means that the indicators of $X_{3}$ are significant at $\alpha=5 \%$.

d. $\mathrm{X}_{4}$ (Tax Sanctions) with a covariance level of 4.229, standard error of (0.581) and t-value of 7.280 (> 1.96), which means that the indicators of $\mathrm{X}_{4}$ are significant at $\alpha=5 \%$.

e. $\mathrm{X}_{5}$ (Quality of Service) with a covariance level of 12.977, standard error of (1.783) and $t$ value of 7.280 (> 1.96), which means that the indicators of $X_{5}$ are significant at $\alpha=5 \%$.

PSI-Y is a matrix that connects the dependent variable with its indicators (manifest / variable observed), with the t-table at $\alpha=5 \%( \pm 1.96)$, thus the result of the indicators is as follow: Y (Taxpayers' Compliance) has a covariance level of 4.295 with a standard error of (0.590) and t-value of 7.280 (> 1.96), which means that the indicators of $\mathrm{Y}$ are significant at $\alpha=5 \%$.

\subsection{Structural Equation Model Analysis}

Table 4 The GAMMA Matrix

\begin{tabular}{|llllll|}
\hline \multicolumn{5}{c|}{ GAMMA } \\
& $\mathrm{X}_{1}$ & $\mathrm{X}_{2}$ & $\mathrm{X}_{3}$ & $\mathrm{X}_{4}$ & $\mathrm{X}_{5}$ \\
\hline
\end{tabular}




\begin{tabular}{|c|c|c|c|c|c|}
\hline & ------ & -------- & -------- & -------- & ------ \\
\hline $\begin{array}{l}-- \\
\end{array}$ & -0.054 & 0.281 & 0.519 & 0.043 & - \\
\hline$(0.060)$ & (0.061) & $(0.047)$ & $(0.122)$ & $(0.105)$ & \\
\hline 3.320 & -0.896 & 5.971 & 4.242 & 0.408 & - \\
\hline
\end{tabular}

Source: Processed Primary Data

The GAMMA matrix shows the influence of exogenous latent variables on endogenous latent variables, of which the results are explained as follows:

a. The beta of $X_{1}$ is -0.054 , with a Standard Error (SE) of (0.061) and t-value of -0.896 (between $-1,96$ and 1.96) proving that there is no significant influence at $5 \%$ level.

b. The beta of $\mathrm{X}_{2}$ is 0.281 , with a Standard Error (SE) of $(0.047)$ and $t$-value of 5.971 (> 1.96) proving that there is a significant influence at $5 \%$ level.

c. The beta of $\mathrm{X}_{3}$ is 0.519 , with a Standard Error (SE) of $(0.122)$ and $t$-value of $4.242(>1.96)$ proving that there is a significant influence at $5 \%$ level.

d. The beta of $\mathrm{X}_{4}$ is 0.043 , with a Standard Error (SE) of (0.105) and t-value of 0.408 (between -1,96 and 1.96) proving that there is no significant influence at 5\% level.

e. The beta of $\mathrm{X}_{5}$ is -0.199 , with a Standard Error (SE) of $(0.060)$ and $t$-value of $-3.320(<1.96)$ proving that there is a significant influence at $5 \%$ level.

The output of the equation model above also produces a path diagram that displays the structural model with $\mathrm{t}$ values, whereas the numbers that appear in the path diagram are the same as the text output above that has been analyzed.

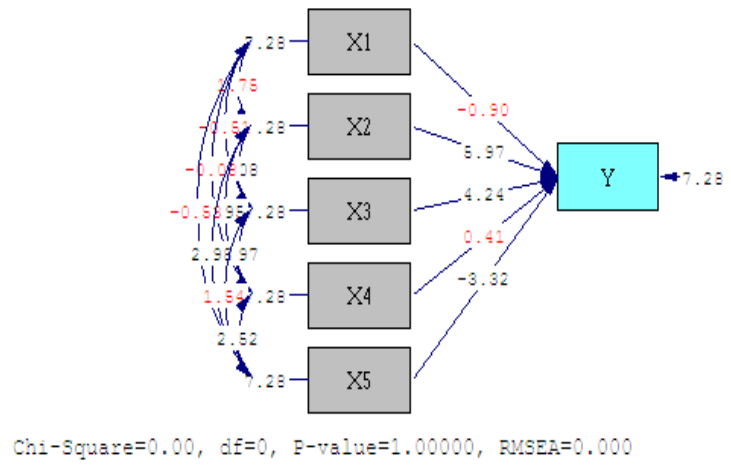

\section{Figure 4 Path Diagram}

This hypothesis testing phase was done to test the research hypotheses that had been proposed previously. The tests of these hypotheses were based on processed research data using the Structural Equation Model (SEM) with Lisrel 8.8 software. The tests of these hypotheses were done by comparing the t-statistics with t-table $(\alpha=5 \%$, the critical value is \pm 1.96 ). If the result of data analysis indicates a value that meets the requirement, then the proposed research hypothesis can be accepted. In detail, the results of hypothesis testing will be discussed as follows:

\subsubsection{Test of Hypothesis 1}

$\mathrm{H}_{1}$ : Self-assessment system has a positive influence on personal taxpayers' compliance.

The results of the Structural Model with the t-statistics of 0.896 (between -1,96 and 1.96) means that $\mathrm{H}_{1}$ was rejected. It can be concluded that there is no significant influence of $\mathrm{X}_{1}$ (Self Assessment) on $\mathrm{Y}$ (Personal Taxpayers' Compliance) at 5\% significance level. In this study, it shows that the empowerment of taxpayers which is the goal of the self-assessment system has not been achieved. This is probably due to the fact that there are still many taxpayers who have not been able to calculate the amount of taxes they owe, along with frequent changes in tax regulations but this is not balanced with sufficient socialization to the public. Taxpayers become confused, complicated in calculating, paying, and reporting their taxes.

The hypothesis that has been developed and tested in this study is in common with that of previous study by [13] mentioning that the self-assessment system has a pretty good influence on taxpayers' compliance in fulfilling their obligations.

\subsubsection{Test of Hypothesis 2}

$\mathrm{H}_{2}$ : Tax knowledge has a positive influence on personal taxpayers' compliance.

The results of the Structural Model with the t-statistics of 5.971 (> 1.96) means that $\mathrm{H}_{2}$ was accepted. It can be concluded that there is a significant influence of $\mathrm{X}_{2}$ (Tax Knowledge) on Y (Taxpayers' Compliance) at 5\% significance level. The hypothesis that has been developed and tested in this study is in common with that of previous study conducted by [17] [4] [11], in which the higher the level of tax knowledge is, the higher the taxpayers' compliance will occur.

\subsubsection{Test of Hypothesis 3}

$\mathrm{H}_{3}$ : Moral Responsibility has a positive influence on Personal Taxpayers' Compliance.

The results of the Structural Model with the t-statistics of 4,242 (> 1.96) means that $\mathrm{H}_{3}$ was accepted. It can be concluded that there is a significant influence of $\mathrm{X}_{3}$ (Moral Responsibility) on Y (Taxpayers' Compliance) at 5\% significance level. The hypothesis that has been developed and tested in this study is similar to that of previous study conducted by [10] whereas the higher the level of moral responsibility of the taxpayers is, the higher the taxpayers' compliance will be. On contrast, [2] stated that moral obligation does not have significant effect on taxpayers' compliance.

\subsubsection{Test of Hypothesis 4}

$\mathrm{H}_{4}$ : Tax Sanctions has a positive influence on Personal Taxpayers' Compliance. 
The results of the Structural Model with t-statistics of 0.408 (between $-1,96$ and 1.96) means that $\mathrm{H}_{4}$ was rejected. It can be concluded that there is no significant influence of $\mathrm{X}_{4}$ (Tax Sanctions) on Y (Taxpayers' Compliance) at 5\% significance level. Most individual taxpayers prefer conducting tax avoidance to paying the taxes properly. Many individual taxpayers know that taxes are used for state financing. Only few taxpayers report and pay taxes voluntarily, because they do not believe that these taxes will be used for state financing purposes and there are many government officials who are stumble in corruption cases. Individual taxpayers tend to choose not to comply, because they are considered more detrimental to pay the taxes properly. There is no difference in paying taxes correctly or incorrectly, because both are considered detrimental to individual taxpayers. This is why the applicable tax sanctions are deemed unable to increase the compliance of individual taxpayers.

The hypothesis developed and tested in this study contradicts and weakens the justification from the previous study conducted by [21] [16] [18], but this result is in accordance with [10], in which although tax sanctions are getting tighter, it does not affect the taxpayers' compliance.

\subsubsection{Test of Hypothesis 5}

$\mathrm{H}_{5}$ : Service Quality has a positive influence on Personal Taxpayers' Compliance.

The results of the Structural Model with t-statistics of $3.320(<-1.96)$ means that $\mathrm{H}_{5}$ was accepted. It can be concluded that there is a significant influence of $\mathrm{X}_{5}$ (Service Quality) on Y (Taxpayers' Compliance) at 5\% significance level. The hypothesis that has been developed and tested in this study has a similarity and strengthens the justification from the previous studies conducted by [10], [15], [5], but is not in accordance with the study by [16].

\section{CLOSING}

\subsection{Conclusions}

There are 5 (five) conclusions as the results of this study, namely:

a. Self-assessment system does not have significant influence on personal taxpayers' compliance.

b. Tax knowledge has a positive and significant influence on personal taxpayers' compliance.

c. Moral responsibility has a positive and significant influence on personal taxpayers' compliance.

d. Tax sanctions does not have significant influence on personal taxpayers' compliance.

e. Service quality has a positive and significant influence on personal taxpayers' compliance.

\subsection{Suggestions}

First, further research needs to be added with variables that have direct effects on increasing the taxpayers' compliance such as nationalism, tax incentives, transparency in the management of state finances, and the improvement of tax regulations that can support business activities.

Second, in making regulations, regulators should always consider the ease of taxpayers in paying taxes.

Third, further research should avoid the cases of correction in the field of taxation, so that taxpayers can voluntarily pay the taxes for national development purposes.

\subsection{Research Implications}

The knowledge of taxpayers on tax regulations, the moral responsibilities of citizens in paying taxes, and the service quality of tax officers greatly affect the taxpayers' compliance. This results in theoretical supports from previous researches [17] [4] [10], while the government, in this case the General Directorate of Tax, can increase state revenues from the tax sector through the increase of understanding / knowledge of taxpayers, in addition to understanding tax regulations and the importance of tax revenue for the State so that the needs of the State can be borne by every Indonesian citizen. Besides, the improvement in service quality is always conducted, as proven by the convenience provided by the government in calculating, depositing, and reporting the taxes in conventional way and through online system.

\subsection{Research Limitations}

First, the variables are limited to the self-assessment system, tax knowledge, moral responsibility, tax sanctions, and service quality taken from random (primary) questionnaire data.

Second, since the data was taken from the questionnaire from individual taxpayers who own a business, it does not rule out the answers provided that are not honest so that the results obtained in this research are not in accordance with the existing reality.

Third, the questionnaire does not pay attention to the age, gender, and line of business of the respondents.

Fourth, the researcher did not accompany the respondents in filling-out the questionnaire, so it is possible that the taxpayers did not understand how to answer the questionnaire correctly.

\section{REFERENCES}

[1] Alm, J., Kirchler, E., \& Muehlbacher, S. (2012). Combining Psychology and Economics in the Analysis of Compliance: From Enforcement to Cooperation. Economic Analysis and Policy, 42(2), 133-151.

[2] Ayu, Ivan (2018). Analysis of Factors that Influence Taxpayers Compliance in Fulfilling Taxation Obligations. Journal of Accounting Auditing and Business - No.1, Vol.2, 2018 10.24198/jaab.v1i2.18270. 
[3] Carolina, Verani dan Simanjuntak, Timbul H. (2011). Pengaruh Tax Knowledge dan Persepsi Tax Fairness terhadap Tax Compliance Wajib Pajak Badan yang Terdaftar di KPP Madya Bandung. Seminar Nasional "Problematika Hukum dalam Implementasi Bisnis dan Investasi (Perspektif Multidisipliner)".

[4] Eddy, Endah Purnama Sari dan Carolina, Verani. (2015). Pengaruh Tingkat Pengetahuan Perpajakan Wajib Pajak Orang Pribadi Terhadap Kepatuhan Wajib Pajak pada Fakultas Ekonomi Universitas Kristen Maranatha. Jurnal Akuntansi, 7(1). hal.1-13.

[5] Emmy Indrayani, Euphrasia Suzy Suhendra (2017). The influencing factors of personal tax compliance on reporting annual income tax return, Jurnal Ekonomi Bisnis Volume 22 No.3, Desember 2017.

[6] Fauziati, Minovia, Musli dan Nasrah. (2016). The Impact of Tax Knowledge on Tax Compliance Case Study in Kota Padang, Indonesia. Jounal of Advanced Research in Business and Management Studies, 2(1). pp: 22-30.

[7] Ghozali, Imam dan Fuad. (2005). "Structural Equation Modelling" Teori, Konsep dan Aplikasi dengan program Lisrel 8.54, Badan Penerbit Universitas Diponegoro Semarang.

[8] Hair, J. F., Anderson, Rolph E., Tatham, Ronald L dan Black, William.C. (1998). Multivariate Data Analysis. $5^{\text {th }}$ edition. Prentice Hall International: UK.

[9] Hendra Hadiwijaya and Febrianty (2019), The Effect of Service Quality and Tax Sanctions on Service Satisfaction, Etikonomi, Volume 18 (2), 2019: 197 208 P-ISSN: 1412-8969; E-ISSN: 2461-0771.

[10] Indriyani, Arika P. dan I. M. Sukartha. (2014). Tanggung jawab Moral, Kesadaran Wajib Pajak, Sanksi Perpajakan dan Kualitas Pelayanan Pada Kepatuhan Pelaporan Wajib Pajak Badan, E-Jurnal Akuntansi Universitas Udayana., 7(2). hal 431-443.

[11] Khoirul Aswar, Ermawati, Tresia Risda Saragih (2019). The Influencing Factors on Taxpayer Compliance: A Conceptual Approach. Information Management and Business Review (ISSN 2220-3796) Vol. 11, No. 4, pp. 27-32, December 2019

[12] Lasmana, M.S dan Heru Tjaraka. (2011). Pengaruh moderasi sosio demografi terhadap hubungan antara moral-etika pajak dan tax avoidance pajak penghasilan wajib pajak di KPP surabaya. Majalah Ekonomi. 21(2). Hal. 185-197

[13] Lasmaya, S Mia dan Fitriani, Neni Nur. (2017). Pengaruh Self Assesment System Terhadap Kepatuhan Wajib Pajak. Jurnal Computech \& Bisnis, Vol.11, No.2, hal $69-78$
[14] Mardiasmo. (2011). Perpajakan Edisi Revisi. Yogyakarta: Andi.

[15] Nilgün Serima Betül İnamb, Dilek Muratc (2014) Factors Affecting Tax Compliance of Taxpayers: The Role of Tax Officer The Case of Istanbul and Canakkale, Business and Economics Research Journal Volume 5 Number 22014 pp. 19-31 ISSN: 1309-2448.

[16] Oktaviane, Lidya Winerungan. (2013). Sosialiasasi Perpajakan, Pelayanan Fiskus dan Sanksi Perpajakan terhadap Kepatuhan WPOP di KPP Manado dan KPP Bitung. Jurnal EMBA. 1(3). Hal 960 - 970.

[17] P. Fauziati, A. F. Minovia, R. Y. Muslim, and R. Nasrah (2016). The Impact of Tax Knowledge on Tax Compliance Case Study in Kota Padang, Indonesia Journal of Advanced Research in Business and Management Studies. ISSN (online): 2462-1935 | Vol. 2, No. 1. Pages 22-30, 2016.

[18] Sabaruddin Yuswar Z. Basri, Susi Dwimulyani, (2018). factors affecting individual taxpayer compliance with practice self assessment system as intervening variable. Journal of Entrepreneurship, Business and Economics ISSN 2345-4695 2018, 6(1), 116-143.

[19] Sedyaning Rahayu (2015), pengaruh tanggung jawab moral, kesadaran wajib pajak, sanksi perpajakan, dan kualitas pelayanan pada kepatuhan pelaporan wajib pajak orang pribadi (studi empiris pada kpp pratama klaten), Universitas Muhammadiyah Surakarta.

[20] Siti Resmi (2019). Perpajakan Indonesia, Teori dan Kasus Edisi 11, Salemba Empat, Jakarta.

[21] Susmiatun, Kusmuriyanto. (2014). Pengaruh Pengetahuan Perpajakan, Ketegasan Sanksi Perpajakan dan Keadilan Perpajakan Terhadap Kepatuhan Wajib Pajak UMKM di Kota Semarang. Accounting Analysis Journal 3(3). hal 378-386.

[22] Supriyati. (2012). Dampak Motivasi dan Pengetahuan Perpajakan Terhadap Kepatuhan Wajib Pajak . Jurnal Investasi. Vol 8 No.1 Juni 2012.

[23] Walsh, K. (2013). Understanding taxpayer behaviour-new opportunities for tax administration. The Economic and Social Review, 43(3, Autumn), 451475.

[24] Waluyo (2019). Perpajakan. Edisi 12, Salemba Empat Jakarta.

[25] https://www.kemenkeu.go.id/media/13995/apbnkita-desember-2019

[26] https://www.kemenkeu.go.id/media/11213/bukuinformasi-apbn-2019 